\title{
The SouthEast Asian Time-series Study (SEATS) and the biogeochemistry of the South China Sea-An overview
}

\author{
George T.F. Wong ${ }^{\mathrm{a}, \mathrm{b}, *}$, Teh-Lung $\mathrm{Ku}^{\mathrm{c}}$, Margaret Mulholland ${ }^{\mathrm{b}}$, \\ Chun-Mao Tseng ${ }^{\mathrm{d}, \mathrm{e}}$, Dong-Ping Wang ${ }^{\mathrm{f}}$ \\ ${ }^{a}$ Research Center for Environmental Changes, Academia Sinica, 128 Academia Road Section 2, Nankang, Taipei 115, Taiwan, ROC \\ ${ }^{\mathrm{b}}$ Department of Ocean, Earth and Atmospheric Sciences, Old Dominion University, Norfolk, VA 23529-0276, USA \\ ${ }^{\mathrm{c}}$ Department of Earth Sciences, University of Southern California, Los Angeles, CA 90089, USA \\ ${ }^{\mathrm{d}}$ National Center for Ocean Research, National Taiwan University, P.O. Box 23-13, Taipei, Taiwan, ROC \\ ${ }^{\mathrm{e}}$ Institute of Oceanography, National Taiwan University, P.O. Box 23-13, Taipei, Taiwan, ROC \\ ${ }^{\mathrm{f}}$ Marine Sciences Research Center, Stony Brook University, Stony Brook, NY 11794, USA
}

Accepted 10 May 2007

Available online 31 July 2007

\begin{abstract}
As part of the time-series program in the Joint Global Ocean Flux Study (JGOFS), the major objective of the multidisciplinary and multi-institutional SouthEast Asian Time-series Study (SEATS) is to investigate through direct observations the processes that influence the carbon cycle and bioactive elements in the intra-annual to decadal time scale. The SEATS site is situated at $18.3^{\circ} \mathrm{N}$ and $115.5^{\circ} \mathrm{E}$ in the tropical oligotrophic northern South China Sea. Among the active time-series stations, it is located at the lowest latitude and it is the only one located in a marginal sea. The major defining environmental characteristics at this site include: oligotrophic water, outside the influence of major rivers, high surface temperature with little seasonality, strong and persistent stratification, thin mixed layer, shallow top of the nutricline depth, deep photic zone, distinct monsoonal seasons, frequent traverses of tropical cyclones, and a high depositional flux of aerosols. Given these environmental conditions, a sitespecific hypothesis in SEATS is that the interactions between the upper waters and the atmosphere constitute a major controlling mechanism of the biogeochemistry in the northern South China Sea. The SEATS station has been occupied at approximately seasonal intervals since 1999. The results obtained primarily between 1999 and 2003 in the initial phase of this study are presented here. In contrast to the generally accepted notion that seasonal variations in the tropical waters are minimal, well defined, and regular seasonal patterns were observed in the carbon cycle, the nutrient dynamics and the biological community structure in the northern South China Sea. In the carbon cycle, superimposed on the large seasonal signals were the more subtle inter-annual variations of progressive increases in the mixed-layer $\mathrm{CO}_{2}$ fugacity $\left(\mathrm{fCO}_{2}\right)$ and total dissolved $\mathrm{CO}_{2}\left(\mathrm{TCO}_{2}\right)$ that also were observed in other time-series stations. This suggests that the absorption of $\mathrm{CO}_{2}$ by the oceans in response to the increase in atmospheric $\mathrm{CO}_{2}$ in modern times may well be globally manifested. The nutrient dynamics indicate that $\mathrm{N}_{2}$ fixation could play a key role in keeping the nutrient cycle in balance in the northern South China Sea.
\end{abstract}

(C) 2007 Elsevier Ltd. All rights reserved.

Keywords: South China Sea; Time-series study; Carbon cycle; Nutrient cycle; Biological community structure; Biogeochemistry

\footnotetext{
*Corresponding author. Research Center for Environmental Changes, Academia Sinica, 128 Academia Road Section 2, Nankang, Taipei 115, Taiwan, ROC. Fax: +886227833584 .

E-mail address: gtfwong@gate.sinica.edu.tw (G.T.F. Wong).
} 


\section{Introduction - the origin of the SouthEast Asian Time-series Study}

The SouthEast Asian Time-series Study (SEATS) was initiated as a result of a series of events in Taiwan that occurred in concert with some major international oceanographic initiatives in the 1990s. The oceanographic community in Taiwan instituted its first multidisciplinary multi-institutional oceanographic study in 1989 when the Kuroshio Edge Exchange Processes (KEEP) study was initiated (Wong et al., 2000a). This project allowed oceanographers in Taiwan to develop the capability to mount sustained oceanographic cruises, to obtain high-quality standard hydrographic data, and to collect samples by using moored sediment traps (Wong et al., 2000b; Liu et al., 2003). While the KEEP study was in progress, the physical oceanographers in and outside Taiwan launched the South China Sea Monsoon Experiment (SCSMEX). Several moorings were deployed and maintained with Acoustic Doppler Current Profilers (ADCP), current meters, and thermister chains in the northern South China Sea (SCS). Data from these moorings demonstrated that, in contrast to the prevailing view that seasonal variations in the composition of the mixed layer are minimal in low-latitude waters (Parsons et al., 1977; Pinet, 2006), extensive variability can be found in the tropical SCS.

In 1998, the National Science Council of Taiwan established the National Center for Ocean Research (NCOR) and one of the charges to the center was to engage in cutting edge research in the oceanographic sciences. A science advisory board, composed mostly of overseas ocean scientists of Chinese descent, was formed and asked to help to design and establish large-scale multi-disciplinary experiments at the center. On the international scene, the role of the ocean in regulating the concentration of atmospheric carbon dioxide had become an area of intense scientific as well as socio-economic interests, and the oceanographers in the United States initiated the US Global Ocean Flux Study (USGOFS) in 1984 (Brewer et al., 1986). This evolved into the international Joint Global Ocean Flux Study (JGOFS) in 1987 under the auspices of the Scientific Committee on Oceanic Research (SCOR) and the International Geosphere and Biosphere Program (IGBP) (SCOR, 1992; McCarthy, 2000; Buesseler, 2001). A key component of the JGOFS program was the two time-series studies off Bermuda (the Bermuda Atlantic Time- series Study, BATS) and Hawaii (Hawaii Ocean Time-series, HOT) (USGOFS, 1986; Wiebe et al., 1987). These studies brought exciting new insights on the ocean as a biogeochemical system and prompted a re-examination of some long-held paradigms (Karl et al., 2001, 2003). The first special issue on the time-series studies appeared in DeepSea Research II in 1996 (Karl and Michaels, 1996). Time-series studies also have been recognized as being conducive to building and augmenting infrastructure for oceanographic studies in a country (USGOFS, 1986). Against such a backdrop, a timeseries study in the northern SCS was recommended by the NCOR advisory board. The proposal was promptly accepted by the Center and the SEATS came to being in 1998. It was recognized as part of the JGOFS program in 1999 (Shiah et al., 1999).

\section{The northern South China Sea: environmental setting}

The SCS is the largest marginal sea of the world (Sverdrup et al., 1942; Chen et al., 2001). The sea lies in a northeast to southwest orientation, extending in a north-south direction from approximately $23^{\circ} \mathrm{N}$ at the southern coasts of Taiwan and China to $3^{\circ} \mathrm{S}$ at the coasts of Borneo and Sumatra; and, in an east-west direction from $102^{\circ} \mathrm{E}$ at the coasts of the Malaysian Peninsula to $121^{\circ} \mathrm{E}$ along the western coasts of the Philippine Islands (Fig. 1). The SCS is connected to the East China Sea in the north through the Taiwan Strait, to the Java Sea in the south through the Karimata Strait, and toward the east to the Sulu Sea through the Mindoro Strait and to the western Philippine Sea of the western North Pacific through the Luzon Strait. The northwestern and southern boundaries of the SCS have extensive shelf systems along the southern coasts of China and between the northern coasts of Borneo and the southern coasts of Vietnam. An extension of the shelf system in the north forms the Gulf of Tonkin while an extension of the shelf system in the south, the Sunda Shelf, forms the Gulf of Thailand. In contrast, the shelf is quite narrow along the eastern and western boundaries of the SCS: along the west coast of the Philippines (Luzon Island) and the eastern shore of southern Vietnam. The SCS covers an area of $3.5 \times 10^{6} \mathrm{~km}^{2}$ (Huang et al., 1994; Chen et al., 2001). While its maximum depth can exceed $5000 \mathrm{~m}$, its mean depth is only $1350 \mathrm{~m}$ (Chen et al., 2001). The corresponding volume is about $4.7 \times 10^{6} \mathrm{~km}^{3}$. Thus, in comparison to the major 
ocean basins, while the SCS is large and deep enough to mimic some of their behaviors, it is also noticeably smaller and more confined (Table 1).

A multitude of rivers drain into the SCS. Most of these empty into the SCS from the west after they

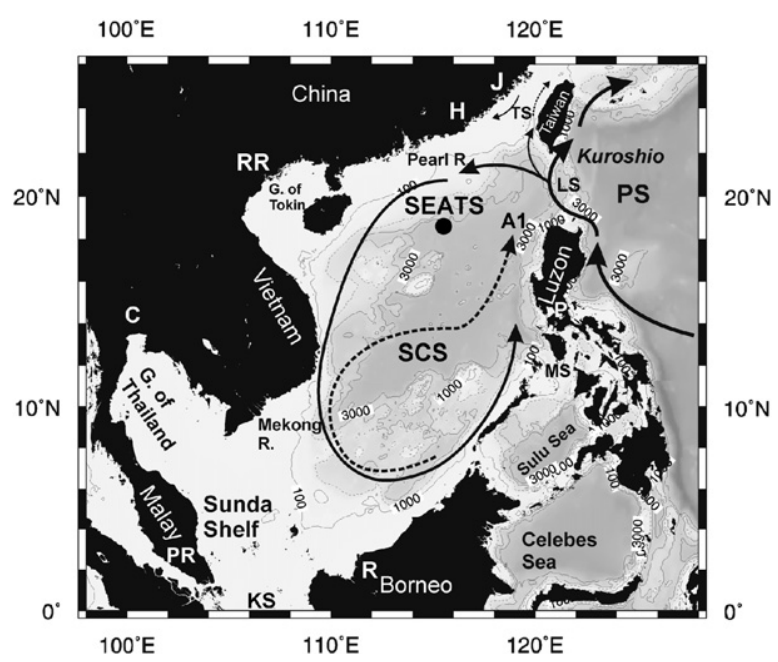

Fig. 1. The study area. The solid line in the South China Sea (SCS) represents the basin wide cyclonic gyre in the winter. The dashed line indicates the eastward jet off the coast of Vietnam and the anticylonic gyre over the southern half of the sea during the summer. The Kuroshio and its intrusions into the northern South China Sea are also shown schematically around the Luzon Strait. KS - Karimata Strait; LS - Luzon Strait; MS - Mindoro Strait; PS-Philippine Sea; TS-Taiwan Strait. The locations where the major rivers reach the SCS are also shown: C-Chao Phraya; H-Hanjiang; J-Jiulongjiang; P-Pasig River; PRPahang River; R-Rajang River; RR-Red River. have passed through densely populated areas in southern China and in the Indo-Chinese Peninsula. The largest among them are the Zhujiang (Pearl River) and the Mekong River, which reach the SCS at 22 and $10^{\circ} \mathrm{N}$, respectively, with flow rates of 316 and $470 \mathrm{~km}^{3}$ year $^{-1}$, respectively. The lesser rivers which flow into the SCS from the west include the Jiulongjiang and the Hanjiang from southern China and the Pahang River from the Malay Peninsula. The Red River from northern Vietnam drains into the Gulf of Tonkin. From the east, the Pasig River and the Rajang River empty into the SCS from the Luzon Island and Borneo, respectively. The Chao Phraya drains into the Gulf of Thailand. These rivers bring an abundance of terrestrial material into the SCS and contribute to high sedimentation rates, at several $\mathrm{cm} \mathrm{kyear}^{-1}$ (Wang et al., 1995; Lee et al., 1999), much higher than those observed in the major deep ocean basins. These rivers are also nutrient-rich (Zhang, 1996). However, the basinwide surface circulation gyres effectively isolate the interior of the SCS proper from the influence of the land-runoff. As a result, the deep central SCS is still oligotrophic like the interior of the major ocean basins (Gong et al., 1992). Precipitation exceeds evaporation in the SCS, especially in the southern SCS (Chen et al., 2001). In the northern SCS, as indicated by the climatological averages between 1971 and 2000 in Hong Kong at 22 N (Hong Kong Observatory Climatological Information Service; Fig. 2), the annual total precipitation, evaporation and excess precipitation were 2382, 1343 and

Table 1

Some characteristics of the South China Sea

\begin{tabular}{|c|c|c|}
\hline Area $\left(10^{6} \mathrm{~km}^{2}\right)$ & 3.5 & Huang et al. (1994), Chen et al. (2001) \\
\hline Average depth (m) & 1350 & Chen et al. (2001) \\
\hline Volume $\left(10^{6} \mathrm{~km}^{3}\right)$ & 4.7 & \\
\hline Annual precipitation $\left(\mathrm{mm} \mathrm{year}^{-1}\right)$ & 2000 & Huang et al. (1994) \\
\hline \multicolumn{3}{|l|}{ River inflow $\left(\mathrm{km}^{3}\right.$ year $\left.^{-1}\right)$} \\
\hline Zhujiang & 316 & Zhang et al. (1994), Zhang (1995) \\
\hline Mekong & 470 & Milliman and Meade (1983) \\
\hline Red River & 123 & Milliman and Meade (1983) \\
\hline Jiulongjiang & 15 & Zhang et al. (1994), Zhang (1995) \\
\hline Hanjiang & 30 & Zhang et al. (1994), Zhang (1995) \\
\hline \multicolumn{3}{|l|}{ Chao Phraya } \\
\hline \multicolumn{3}{|l|}{ Pahang River } \\
\hline \multicolumn{3}{|l|}{ Pasig River } \\
\hline \multicolumn{3}{|l|}{ Rajang River } \\
\hline Mixed layer depth (northern South China Sea, m) & 20 (summer) & Wong et al. (2002), Tseng et al. (2005) \\
\hline & 80 (winter) & \\
\hline Sea surface temperature (central South China Sea, ${ }^{\circ} \mathrm{C}$ ) & $>22$ & Chao et al. $(1996 a, b)$ \\
\hline Surface salinity (central South China Sea) & Mostly $<34$ & Shaw and Chao (1994) \\
\hline
\end{tabular}




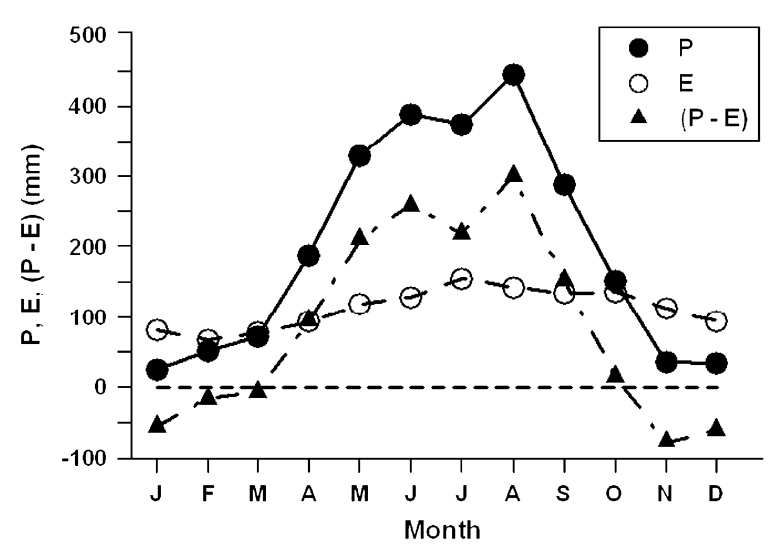

Fig. 2. Climatological monthly variations in the rates of precipitation $(P)$, evaporation $(E)$ and net precipitation $(P-E)$ between 1971 and 2000 in Hong Kong.

Table 2

Annual water budget of the South China Sea ${ }^{a}$

\begin{tabular}{ll}
\hline & Flux \\
\hline $\begin{array}{l}\text { Inputs } \\
\quad \text { Surface inflow of Kuroshio water from }\end{array}$ & $2.7 \times 10^{-1}$ \\
$\quad$ western Philippine Sea & $3.7 \times 10^{-2}$ \\
$\quad \begin{array}{l}\text { Inflow of deep water from the western } \\
\text { Philippine Sea }\end{array}$ & $1.8 \times 10^{-2}$ \\
$\quad \begin{array}{l}\text { Surface inflow from Sulu Sea } \\
\text { Riverine input }\end{array}$ & $1.7 \times 10^{-3}$ \\
$\quad$ Net precipitation & \\
Outflow & $-2.5 \times 10^{-3}$ \\
$\quad$ Surface outflow to western Philippine Sea & $-2.4 \times 10^{-1}$ \\
$\quad$ Net outflow at intermediate depths to the & $-5.8 \times 10^{-2}$ \\
western Philippine Sea & \\
Net surface outflow to Java Sea & $-1.8 \times 10^{-2}$ \\
Surface outflow to East China Sea & $-1.1 \times 10^{-2}$ \\
\hline
\end{tabular}

${ }^{a}$ Adopted from Chen et al. (2001). Water fluxes are in $\mathrm{km}^{3}$ year $^{-1}$.

$1039 \mathrm{~mm}$, respectively. Most of the excess was between April and September when over 90\% of the annual precipitation occurred. Inputs of fresh water from terrestrial runoffs and atmospheric deposition reduce the surface salinity in most regions of the central SCS to below 34 (Gong et al., 1992; Shaw and Chao, 1994). Chen et al. (2001) have proposed a water budget for the wet and dry seasons of the SCS. The annual sum is shown in Table 2.

Since the SCS is situated in the tropical zone, its sea-surface temperature is consistently high. In the central SCS, sea-surface temperature does not drop below $22^{\circ} \mathrm{C}$. In the summer months, it can exceed $29^{\circ} \mathrm{C}$ in some regions (Chao et al., 1996a, b). As a result, the upper water column is persistently well stratified (Shaw and Chao, 1994). The photic zone depth is also persistently deep throughout the year. In the northern SCS, it stays at around $85 \mathrm{~m}$ and it exceeds the mixed-layer depth and the top of the nutricline in most of the year (Tseng et al., 2005). Thus, the availability of light is not a limiting factor of primary production in the central SCS. Instead, it is oligotrophic and primary production is limited primarily by the availability of the nutrients.

The surface waters in the SCS exchange freely with those in the East China Sea, the Java Sea, the Sulu Sea and the western Philippine Sea. However, subsurface waters flow into the SCS primarily from the western Philippine Sea through the Luzon Strait as a result of the shallow sill depths connecting the other seas to the SCS. Tropical Water, originating from the pool of high-salinity water found near the international dateline at $20-30^{\circ} \mathrm{N}$ in the North Pacific (Suga et al., 2000), appears as a salinity maximum at around $150 \mathrm{~m}$ in the SCS (Fig. 3). The North Pacific Intermediate Water, which appears as a salinity minimum (Fig. 3) centered around $500 \mathrm{~m}$, can be traced to its source in the subpolar regions in the North Pacific (You, 2003). Deep water in the western Philippine Sea overflows the sill that separates it from the SCS at about $2200 \mathrm{~m}$ and fills the deep SCS. Consequently, the composition of

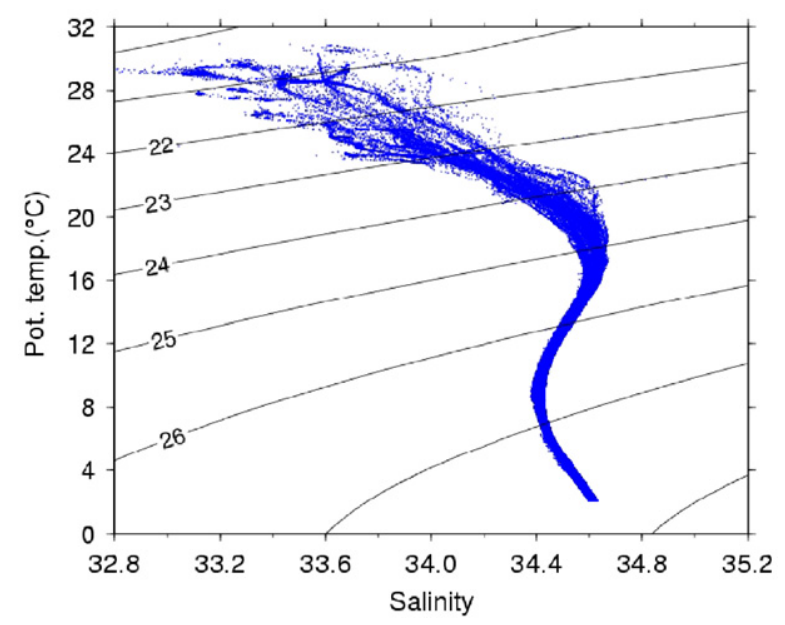

Fig. 3. The relationships between potential temperature and salinity at the SEATS station between September 1999 and October 2003. Tropical water, which centers at about $150 \mathrm{~m}$, appears as the salinity maximum at salinities of around 34.6 while North Pacific Intermediate Water, which centers at about $500 \mathrm{~m}$, appears as the salinity minimum at salinities around 34.4 . 
deep water in the SCS below this depth is rather uniform and has characteristics similar to those in the western Philippine Sea at this depth. A mass balance of inflowing deep waters from the western Philippine Sea is maintained primarily by upwelling and mixing with the shallower North Pacific Intermediate Water, and, an outflow at an intermediate depth to the western Philippine Sea through the Luzon Strait (Chao et al., 1996b; Liu et al., 2002; Chen, 2005a; Chen et al., 2006a; Li and Qu, 2006). Exchanges of water between the SCS and the western Philippine Sea are rigorous enough that the resulting residence time of the deep water in the SCS is only 50-150 years (Broecker et al., 1986; Gong et al., 1992). The corresponding basin-wide upwelling rate is about $10-20{\mathrm{~m} y e a r^{-1}}^{\text {. A more recent }}$ estimate suggesting a residence time of less than 30 years and an upwelling rate of $90 \mathrm{myear}^{-1}$ indicates that the renewal of the deep water in the SCS may be more rapid than previously thought (Qu et al., 2006). Further, the high upwelling rates result in a thin mixed layer, $20 \mathrm{~m}$ in the summer and up to $100 \mathrm{~m}$ in the winter, and a shallow top of the nutricline, about $60 \mathrm{~m}$ year round (Tseng et al., 2005).

Situated between the western Pacific warm pool and the Tibetan Plateau, the SCS is under the persistent influence of monsoonal winds: a strong northeast monsoon between November and April and a weaker southwest monsoon between June and September. Between these two monsoonal seasons, in May and October, the wind is weak and variable (Liu et al., 2002; Tseng et al., 2005). Spatially, the wind is weaker in the southern part of the SCS south of about $10^{\circ} \mathrm{N}$ (Shaw and Chao, 1994; Chao et al., 1996a). These monsoonal winds play a major role in the oceanography of the SCS. First, the large-scale surface currents are driven to a significant extent by the monsoons so that there is a basinwide cyclonic circulation gyre around the entire SCS proper during the northeast monsoon and an anticyclonic circulation gyre around the southern half of the Sea during the southwest monsoon (Chao et al., 1995, 1996a; Shaw and Chao, 1994; Shaw et al., 1999; Xue et al., 2004; Gan et al., 2006). When the monsoonal winds are weakened, as in El Niño years, the surface circulation also is weakened (Chao et al., 1996a). Second, the monsoonal winds induce coastal upwelling. During the northeast monsoon, upwelling occurs off the northwest coasts of the Luzon Island in the Philippines and along the edge of the Sunda Shelf. In contrast, during the southwest monsoon, there is upwelling off the southeastern coasts of the Indo-Chinese Peninsula (Shaw and Chao, 1994; Shaw et al., 1996; Liu et al., 2002; Xie et al., 2003; Ning et al., 2004). Third, the northeast monsoon can carry central Asian dusts to the northern SCS. Models of atmospheric deposition suggest that this region of the SCS may receive significant aeolian inputs of minerals and iron (Duce et al., 1991; Duce and Tinsdale, 1991; Fung et al., 2000; Gao et al., 2001). Fourth and finally, the combined effect of the strong northeast monsoon and surface cooling in the winter brings nutrientrich water from the upper nutricline into the mixed layer and accounts for the annual maximum in primary production in that season (Tseng et al., 2005).

The SCS is a region where tropical cyclones frequent (Lin et al., 2003). Between 1950 and 2002, an average of 10 , with a minimum of three and a maximum of 20, typhoons traversed the SCS annually (Liu et al., in press). The passing of tropical cyclones can cause entrainment and upwelling of cold and nutrient-replete subsurface water, or "atmospheric pumping", into the mixed layer (Dickey et al., 1998). This episodic injection of nutrients may then elevate primary production in the mixed layer. With a shallow thermocline and a shallow top of the nutricline, the effects of "atmospheric pumping" should be more pronounced in the SCS. Indeed, Lin et al. (2003) reported that the occurrence of the moderate tropical cyclone Kai Tak led to a 30 -fold increase in the concentration of surface chlorophyll $a$, and this one event alone could account for $2-4 \%$ of the annual new production in the SCS.

Given the above environmental characteristics of the northern SCS, there are major similarities and differences between the SEATS site and the other major time-series study sites, HOT and BATS. While all these time-series stations are situated away from the influence of major rivers in oligotrophic waters, the SEATS station distinguishes itself by being located at the lowest latitude in the tropical zone in a marginal sea. Thus, as in other tropical waters, at SEATS, the sea-surface temperature is high, the vertical stratification is persistently strong, and the photic zone is deep year round. In addition, unlike the HOT and BATS stations, the biogeochemistry at the SEATS station also may be heavily influenced by the distinct monsoonal winds, the frequent traverses of tropical cyclones and a high depositional flux of aerosols over the SCS. 


\section{The SouthEast Asian Time-series Study}

\subsection{Goals, objectives and hypotheses}

The primary goals of the JGOFS program are to determine on a global scale the processes controlling the time-varying fluxes of carbon and associated biogenic elements in the ocean, to evaluate the related exchanges with the atmosphere, the seafloor and continental boundaries, and to develop a capability to predict the response of oceanic biogeochemical processes to anthropogenic perturbations, in particular those related to climate change (SCOR, 1990). Within this framework, the time-series stations were established to document some of these processes that occur in intra-annual to decadal time-scale through direct observations and the objectives of the program are fourfold: (1) to observe and interpret the annual and inter-annual variability in the biology and chemistry of the mixed layer and euphotic zone; (2) to observe and interpret the annual and inter-annual variability in the rates of particle flux and the apparent rates of particle remineralization over the water column; (3) to understand the interrelationships between the biological and chemical processes and physical characteristics of the water column; and (4) to provide data on global trends of selected oceanic properties over seasonal and inter-annual time scales (USGOFS, 1990). As one of the time-series studies in the JGOFS program, these are also the general goals and objectives of SEATS. However, given the unique combination of environmental conditions in the northern SCS, an additional site-specific hypothesis in SEATS is that the interactions between the upper water and the atmosphere, specifically atmospheric pumping and atmospheric depositions, constitute a major driving force of the biogeochemistry in the northern SCS.

\subsection{Progressive developments in the SouthEast Asian Time-series Study}

The SEATS program was initiated with a series of six bimonthly test cruises from September 1998 to July 1999 in which a test station, Station A1, was occupied in five of the cruises. This test station was located at $18.9-19.1^{\circ} \mathrm{N}$ and $118.4-118.8^{\circ} \mathrm{E}$ northwest of Luzon Island (Fig. 1). During these cruises, it was learned that, while the capability of obtaining high-quality data on hydrographic properties, the major nutrients and the carbonate system had steadily improved, Station A1 was not an ideal site for a time-series study as its hydrography was heavily influenced by the winter upwelling off the coasts of Luzon Island (Chen et al., 2006b) and the internal waves generated probably around the Luzon Strait (Liu et al., 2006). Thus, at the end of this initial period, it was decided that, in order to minimize these effects, the sampling site should be moved southeastward to Station S1 at $18.0-18.1^{\circ} \mathrm{N}$ and $115.9-116.1^{\circ} \mathrm{E}$. Then, in late 2000 , the SEATS program took over the responsibility for maintaining a mooring with a chain of thermisters and current meters at a nearby location from the waning Taiwanese SCSMEX program. As a result, for logistical reasons, the sampling location was shifted slightly northwestward to the present site, Station $\mathrm{KK}-1$, at $18.2-18.4^{\circ} \mathrm{N}$ and $115.4-115.7^{\circ} \mathrm{E}$ in October 2000 .

The changes in the sampling frequency in SEATS have been driven to a large extent by the availability of ship-time. Two research vessels had been used almost exclusively for SEATS. The smaller $\mathrm{R} / \mathrm{V}$ Ocean Researcher 3, OR3, a 300 t vessel, was used almost exclusively between 1998 and 2001. However, its size placed significant restrictions on the sampling program. On the other hand, the availability of the larger R/V Ocean Researcher 1, OR1, an $800 \mathrm{t}$ vessel, was limited. Thus, while a bimonthly sampling program was initially envisioned, it was apparent before long that such a schedule could not be sustained if a full sampling program were to be sustained by using the Ocean Researcher I. As a result, by 2001, the sampling interval was reduced to an approximately seasonal schedule, and this schedule has been maintained to the present time. As of the end of 2006, Stations S1 and KK-1 have been occupied for 31 times. Between September 1999 and October 2003, they were occupied for 19 times, and the data from this sampling period are the focus of the discussions in this special issue. A listing of the sampling cruises in SEATS during this time period is given in Table 3 .

The field sampling program at SEATS followed approximately the scheme developed at HOT (Karl and Lukas, 1996). The initial analytical program of SEATS was quite modest. Aside from the measurements of temperature, salinity, fluorescence and photosynthetically active radiation by using sensors, discrete water samples were collected for the determination of dissolved oxygen, soluble reactive phosphate (SRP), nitrite, nitrate plus nitrite $(\mathrm{N}+\mathrm{N})$, chlorophyll $a$, total dissolved inorganic 
Table 3

SouthEast Asian Time-series Study (SEATS) cruises

\begin{tabular}{|c|c|c|c|}
\hline Year & Sta & Location & Cruises \\
\hline 1998 & A1 & $\begin{array}{l}18.9-19.1^{\circ} \mathrm{N} \\
118.4-118.8^{\circ} \mathrm{E}\end{array}$ & September (OR3-CR468); November (OR3-CR491) \\
\hline 1999 & Al & & January (OR3-CR500); March (OR3-CR512); May (OR3-CR534); July (OR3-CR549) \\
\hline & $\mathrm{S} 1$ & $\begin{array}{l}18.0-18.1^{\circ} \mathrm{N} \\
115.9-116.1^{\circ} \mathrm{E}\end{array}$ & September (OR3-CR561); November (OR3-CR585) \\
\hline 2000 & $\begin{array}{l}\mathrm{S} 1 \\
\mathrm{KK} 1\end{array}$ & $\begin{array}{l}18.2-18.4^{\circ} \mathrm{N} \\
115.4-115.7^{\circ} \mathrm{E}\end{array}$ & $\begin{array}{l}\text { January (OR3-CR600); March (OR3-CR607); May (OR3-CR629); July (OR3-CR644) } \\
\text { October (OR3-CR657) }\end{array}$ \\
\hline 2001 & KK1 & & February (OR3-CR682); June (OR3-CR716); October (OR3-CR729); December (OR1-CR632) \\
\hline 2002 & KK1 & & March (OR1-CR639); July (OR3-CR794); September (OR1-CR656); November (OR1-CR664) \\
\hline 2003 & KK1 & & January (OR1-CR673); March (OR1-CR674); August (OR1-CR690); October (OR1-CR696) \\
\hline
\end{tabular}

carbon $\left(\mathrm{TCO}_{2}\right)$ and alkalinity. The determination of bacterial production, primary production, $\delta^{13} \mathrm{C}$ in $\mathrm{TCO}_{2}$ and underway partial pressure of carbon dioxide $\left(\mathrm{pCO}_{2}\right)$ were added in around 2002-2003. Measurements of particulate organic carbon (POC) and particulate organic nitrogen (PON) began in late 2003. Other measurements that had been taken on a non-routine basis included the determination of low-level phosphate (Wu et al., 2003), trace metals (Wu et al., 2003; Wen et al., 2006), thorium234, and the enumeration of phytoplankton (Chen, 2005b), including Trichodesmium sp., and zooplankton. The mooring of current meters and thermister chain was lost in 2005 and it has not been reestablished. Instead, a moored sediment trap sampling program was initiated in that same year. The SEATS program has received funding through 2007. Further developments in the program are presently under discussion.

\section{Highlights}

\subsection{The carbon cycle}

\subsubsection{Air-sea exchange of $\mathrm{CO}_{2}$}

Marginal seas have been suggested as a significant global net sink of atmospheric $\mathrm{CO}_{2}$ (Liu et al., 2000; Chen et al., 2003a; Thomas et al., 2004). The suggestion was based primarily on observations from the temperate zone. Recent studies (Rehder and Suess, 2001; Zhai et al., 2005) indicate that the SCS, which is located in the subtropics and tropics, is actually a source of $\mathrm{CO}_{2}$ to the atmosphere in the spring, summer and fall. Tseng et al. (2007), while affirming this finding, found that the open northern SCS does serve as a sink of atmospheric $\mathrm{CO}_{2}$ in the winter. The winter invasion of $\mathrm{CO}_{2}$ is large enough to balance the evasion of $\mathrm{CO}_{2}$ in the other three seasons so that there is little net annual exchange of $\mathrm{CO}_{2}$ between this marginal sea and its overlying atmosphere. Thus, the marginal seas as a whole may be a less important $\mathrm{CO}_{2}$ sink than previously thought, and their role as a net sink on a global scale needs to be re-examined (Cai and Dai, 2004).

Unlike at the HOT and BATS stations, where an increase in $\mathrm{TCO}_{2}$ in the mixed layer with time was accompanied by a net invasion of atmospheric $\mathrm{CO}_{2}$, at the SEATS station, the increase in $\mathrm{TCO}_{2}$ occurred in the absence of any significant net invasion of atmospheric $\mathrm{CO}_{2}$ (Tseng et al., 2007), suggesting that the added $\mathrm{TCO}_{2}$ was originated from outside the local area. Although the uncertainties involved are admittedly large, the estimated rates of increase in $\mathrm{TCO}_{2}$ were of the same magnitude at these three widely dispersed timeseries stations. This may reflect that the effect of the increased absorption of atmospheric $\mathrm{CO}_{2}$ by the surface oceans in response to the increase in anthropogenic $\mathrm{CO}_{2}$ in the atmosphere has propagated globally. Chou et al. (2007) found that the influence of this anthropogenic $\mathrm{CO}_{2}$ can be detected to a depth of about $1000 \mathrm{~m}$ at the SEATS station. As a result of this increased absorption of atmospheric $\mathrm{CO}_{2}$, the saturation depth of aragonitic calcium carbonate has migrated upward by about $100 \mathrm{~m}$ since the Industrial Revolution.

\subsubsection{Mechanisms regulating the distributions of the dissolved and particulate carbon species \\ In the interior SCS, particle settling is the primary mechanism for the export of organic carbon from the upper mixed layer to the deep water. The total}


export was estimated to be about $30 \mathrm{~g}-\mathrm{C} \mathrm{m}^{-2}$ year $^{-1}$ (Hung et al., 2007). In the mixed layer, the $\delta^{13} \mathrm{C}$ of the POC indicates its marine origin with little contribution from terrigenous sources. However, in the deep water, the contribution from terrigenous material becomes conspicuous after the more labile organic matter settling from the mixed layer above has been preferentially remineralized (Liu et al., 2007a). Oxidation of settling organic matter can account for $72 \%$ of the increase in $\mathrm{TCO}_{2}$ in the deep water. The remaining $28 \%$ is due to the dissolution of carbonate (Chou et al., 2007).

In the mixed layer of the interior northern SCS, seasonal variations were detected in the distributions of the inorganic carbonate species (Tseng et al., 2007), dissolved organic carbon, and POC (Hung et al., 2007), and $\delta^{13} \mathrm{C}$ of suspended and sinking particulate organic matter (Liu et al., 2007a). In the winter, the net invasion of atmospheric $\mathrm{CO}_{2}$ and enhanced vertical mixing with the subsurface water played a major role in regulating the concentrations of the inorganic carbonate species. From late winter to the late summer, the effects of biological uptake of carbon and the evasion of $\mathrm{CO}_{2}$ to the atmosphere were dominant. From late summer to the early winter, changes in concentrations of the inorganic carbonate species are governed primarily by changes in salinity and temperature (Tseng et al., 2007). Hung et al. (2007) linked the seasonal variations in the concentrations in particulate and dissolved organic carbon to biological activities. Their export from the mixed layer to the deep water was higher in the winter when primary production was higher. Liu et al. (2007a) suggested that the seasonal variations in the $\delta^{13} \mathrm{C}$ in POC were controlled biologically and could be accounted for by seasonal variations in specific growth rate, enzymatic isotopic fractionation during carbon fixation, cell size and cell wall permeability.

\subsubsection{The organic carbon cycle}

A model of organic carbon cycling in the SCS is shown in Fig. 4. Measurements of primary production in the SCS have been sparse. Ning et al. (2004) reported primary production rates of $142 \pm 125$ g-C m${ }^{-2}$ year $^{-1}$ in the summer and $199 \pm 149$ $\mathrm{g}-\mathrm{C} \mathrm{m}^{-2}$ year $^{-1}$ in the winter, giving an average of $170 \mathrm{~g}_{-} \mathrm{C} \mathrm{m}^{-2}$ year $^{-1}$. Chen (2005b) estimated primary production rates of $120 \mathrm{~g}-\mathrm{C} \mathrm{m}^{-2}$ year $^{-1}$ in the northern SCS. A biological-physical coupled-model study yielded primary production estimates of 130

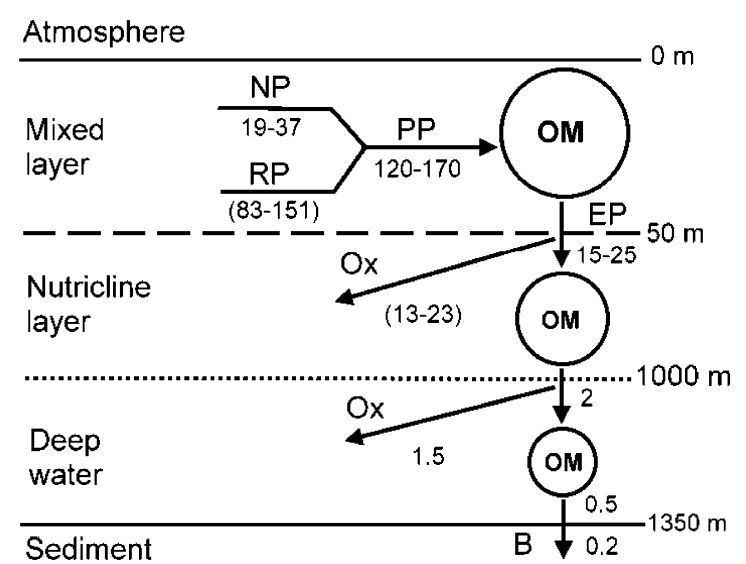

Fig. 4. A schematic diagram outlining the dynamics of particulate organic carbon in the South China Sea. OM-organic matter; $\mathrm{PP}$ - net primary production; $\mathrm{NP}$ - new production; $\mathrm{RP}$ — recycled production; $\mathrm{EP}$ - export production; $\mathrm{Ox}$ — remineralization by the oxidation of organic matter; B-burial. Fluxes are in $\mathrm{g}-\mathrm{Cm}^{-2}$ year $^{-1}$.

and $150 \mathrm{~g}-\mathrm{C} \mathrm{m}^{-2}$ year $^{-1}$ (Liu et al., 2002, 2007b). Thus, the presently available information suggests that the primary production in the SCS falls within the range of $120-170 \mathrm{~g}-\mathrm{C} \mathrm{m}^{-2}$ year $^{-1}$. Nitrate uptake studies suggest that new production is $37 \mathrm{~g}-\mathrm{C} \mathrm{m}^{-2}$ year $^{-1}$ (Chen, 2005b), up to $31 \%$ of the total productivity. Based on the ${ }^{228} \mathrm{Ra}$-nitrate relationship, new production was estimated to be $19 \mathrm{~g}-\mathrm{Cm}^{-2}$ year $^{-1}$ (Cai et al., 2002), up to $16 \%$ of total productivity. The estimate of new production from the distributions of the nutrients, around $30 \mathrm{~g}-\mathrm{C} \mathrm{m}^{-2}$ year $^{-1}$, reported by Hung et al. (2007) falls within this range. All combined, the resulting $f$ ratio in the SCS is on the order of 0.2. The recycled production, estimated as the difference between the primary production and new production, is then

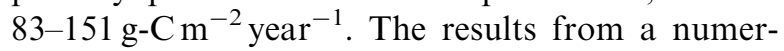
ical modeling study suggest that $12 \%$ of the primary production is exported (Liu et al., 2002). This is equivalent to about $14-20 \mathrm{~g}_{-} \mathrm{C} \mathrm{m}^{-2}$ year $^{-1}$. Using a relationship between ${ }^{234} \mathrm{Th}$ and $\mathrm{POC}$, Cai et al. (2002) estimated an export production of $25 \mathrm{~g}-\mathrm{C} \mathrm{m}^{-2}$ year $^{-1}$. This range of export production, 14-25 g-C m ${ }^{-2}$ year $^{-1}$, overlaps reasonably well with the independently estimated range of new production, $19-37 \mathrm{~g}-\mathrm{C} \mathrm{m}^{-2}$ year $^{-1}$.

Sediment traps deployed at $1000 \mathrm{~m}$ in the northern SCS yielded a settling flux of organic carbon of $2 \mathrm{~g}-\mathrm{C} \mathrm{m}^{-2}$ year $^{-1}$ (Jennerjahn et al., 1992) suggesting that about $90 \%$ of the organic matter produced in the euphotic zone is remineralized in the main 
nutricline between the bottom of the mixed layer, at about $50 \mathrm{~m}$, and $1000 \mathrm{~m}$. The rate of consumption of oxygen in the deep water below $800 \mathrm{~m}$ was estimated to be $0.3-0.6 \mu \mathrm{mol} \mathrm{kg}^{-1}$ year $^{-1}$ (Chen et al., 2001) and the average depth of the SCS is about $1350 \mathrm{~m}$. Therefore, using the average consumption rate of oxygen of $0.45 \mu \mathrm{mol} \mathrm{kg}$ year $^{-1}$, the total consumption of oxygen between 1000 and $1350 \mathrm{~m}$ can be estimated to be on the order of $0.16 \mathrm{~mol} \mathrm{~m}^{-2}$ year $^{-1}$. If the oxidation of organic matter follows the Redfield stoichiometry (Redfield et al., 1963) so that the mole ratio of oxygen consumed and POC remineralized is $138: 106$, then $1.5 \mathrm{~g}_{-} \mathrm{C} \mathrm{m}^{-2}$ year $^{-1}$ is remineralized below $1000 \mathrm{~m}$. This leaves only $0.5 \mathrm{~g}-\mathrm{C} \mathrm{m}^{-2}$ year $^{-1}$ to survive oxidation and reach the seabed. The average sedimentation rate in the SCS over the past several thousand years is about $3 \mathrm{~cm}$ kyear $^{-1}$ (Wang et al., 1995; Lee et al., 1999). The concentration of organic carbon in these sediments is about $0.6 \%\left(\mathrm{w} \mathrm{w}^{-1}\right)$ (Chen et al., 1999). Assuming a porosity of $50 \%$ and a dry sediment density of $2.3 \mathrm{~g} \mathrm{~cm}^{-3}$, the burial rate of organic carbon in this Sea is estimated to be $0.2 \mathrm{~g}^{-\mathrm{C} \mathrm{m}^{-2}}$ year $^{-1}$. This value compares well with the estimated flux of organic carbon reaching the seabed. Relative to the flux of organic matter that settles below $1000 \mathrm{~m}$, we estimate that only $25 \%$ reaches the seabed and only about $10 \%$ of that undergoes permanent burial. In other words, only $0.1-0.2 \%$ of photosynthetically fixed carbon in the mixed layer is likely to be preserved in the sediments. The biogeochemical dynamics of POC in the SCS calculated here agree well with the general scheme for the cycling and burial of organic carbon in the open oceans (Pilson, 1998) and with the global relationship between primary-production normalized carbon accumulation rate and sedimentation rate (Calvert et al., 1991). At a sedimentation rate of $3 \mathrm{~cm} \mathrm{kyear}^{-1}$, the relationship yields a normalized carbon accumulation rate of $0.11 \%$. Using the estimated carbon burial rate and median primary production rate at the SEATS station of 0.2

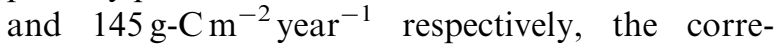
sponding value is $0.14 \%$. The observed settling flux of organic carbon at $1000 \mathrm{~m}$ is also of the same magnitude as that predicted from the general relationship between water depth and carbon flux (Betzer et al., 1984). The reported flux at $1000 \mathrm{~m}$ was $2 \mathrm{~g}_{-} \mathrm{C} \mathrm{m}^{-2}$ year $^{-1}$ (Jennerjahn et al., 1992). In comparison, at this depth and a primary production of $145 \mathrm{~g}-\mathrm{C} \mathrm{m}^{-2}$ year $^{-1}$, the general relationship gives a flux of $6 \mathrm{~g}-\mathrm{C} \mathrm{m}^{-2}$ year $^{-1}$.

\subsection{Nutrient dynamics}

The dominant nutrient fluxes to and from the SCS result from the exchange of intermediate and deep water with the western Philippine Sea through the Luzon Strait. Chen et al. (2001) estimated an export of $1 \times 10^{11} \mathrm{molyear}^{-1}$ of soluble reactive phosphate (SRP) and $1.4 \times 10^{12}$ mol year $^{-1}$ of nitrate from the SCS to the western Philippine Sea at intermediate depths between 350 and $1350 \mathrm{~m}$, and imports of similar magnitudes in deep waters below $1350 \mathrm{~m}$. While the phosphorus budget is reasonably in balance, the total input of nitrate exceeds its removal by $1 \times 10^{11}$ mol year $^{-1}$. This imbalance was accounted for by assuming sedimentary denitrification in excess of nitrogen fixation by the same amount. In the deep SCS, Chen et al. (2001) also estimated oxygen consumption rates of $0.30-0.59 \mu \mathrm{mol} \mathrm{kg}^{-1}$ year $^{-1}$ and corresponding production rates of SRP and nitrate of $0.0035-0.005$ and $0.045-0.054 \mu \mathrm{mol} \mathrm{kg} \mathrm{kear}^{-1}$, respectively.

In the upper ocean, nutrient dynamics are critical in governing the new/export production (Eppley and Peterson, 1979) and the efficiency of the biological pump. The traditional nutrient input terms, namely, winter convection and diapycnal diffusion, are insufficient to account for the geochemical estimates of new production in ocean gyres (McGillicuddy et al., 1998). However, in a marginal sea such as the SCS, benthic nutrient fluxes resulting from sedimentary remineralization of organic matter on the shallow shelves may be an important source of nutrients to the euphotic zone (Liu et al., 2007b). Nonetheless, their effects are conspicuous only in the shallow waters along the coasts. In oligotrophic waters, dinitrogen $\left(\mathrm{N}_{2}\right)$ fixation is a significant source of new nitrogen (Capone et al., 1997; Karl et al., 1997; Gruber and Sarmiento, 1997; Montoya et al., 2004; Capone et al., 2005; Mahaffey et al., 2005). In the northern $\mathrm{SCS}$, the environmental setting is conducive to the occurrence of $\mathrm{N}_{2}$ fixation and its occurrence is consistent with the relative distributions of SRP and nitrate plus nitrite $(\mathrm{N}+\mathrm{N})$, and the isotopic composition of $(\mathrm{N}+\mathrm{N})$ in the upper nutricline (Wong et al., 2002), and a carbon budget (Chou et al., 2006). Wu et al. (2003) and Chen (2005b) suggest that $(\mathrm{N}+\mathrm{N})$ is more limiting than SRP in the SCS so that $\mathrm{N}_{2}$ fixation may be favored. However, while the lack of biologically available nitrogen may promote $\mathrm{N}_{2}$ fixation, the lack of bioavailable iron may limit its occurrence (Wu et al., 
2003). The earlier findings of Wong et al. (2002), which suggest that there may be significant $\mathrm{N}_{2}$ fixation in the SCS, now appear to be confirmed by longer-term records (Wong et al., 2007). Further, if the primary source of nutrients to the euphotic zone in the northern SCS is by vertical mixing, there should be a rapid build-up of SRP in the euphotic zone to a steady-state concentration of $\sim 0.1 \mu \mathrm{M}$, and this is inconsistent with observations. On the other hand, diazotrophic production would draw down phosphorus without a concomitant drawdown of combined nitrogen, preventing such an accumulation and allowing the mixed layer to stay at a steady state. If $\mathrm{N}_{2}$ fixers account for $3-13 \%$ of the net primary production, this balance can be achieved. Nonetheless, the organisms that are responsible for the $\mathrm{N}_{2}$ fixation are still unclear. High abundance of the widely recognized $\mathrm{N}_{2}$ fixer, Trichodesmium sp. and Richelia intracellularis, has not been observed (Chen et al., 2003b, 2004; Chen, 2005b). More recently, the presence of unicellular cyanobacteria with nitrogenase genes has been found, and this organism has been suggested as the potential $\mathrm{N}_{2}$ fixer at the SEATS site (Chou et al., 2006).

Another possible non-traditional source of nutrients to the euphotic zone is through episodic vertical mixing induced by mesoscale eddies (McGillicuddy and Robinson, 1997; McGillicuddy et al., 1998; Oschlies and Garçon, 1998). The occurrence of mesoscale eddies in the SCS has been observed in a number of occasions (Wang et al., 2003). Wu and Chiang (2007) suggest that these mesoscale eddies could have originated in the vicinity of the Luzon Strait as they are shed from the Kuroshio. They may then propagate westwards at a speed of about $0.1 \mathrm{~m} \mathrm{~s}^{-1}$ and influence the hydrography and chemistry at the SEATS station. Seasonally, more eddies are formed in the winter than in the summer.

Paerl (1997) suggested that atmospheric deposition can be a significant source of nutrients for fueling new production. More recently, the significance of atmospherically derived iron on ocean biogeochemistry has been especially noted (Jickells et al., 2005). Lin et al. (2007) reports that the SCS receives atmospheric deposition from multiple sources. In addition to locally generated marine aerosols, anthropogenic aerosols from fossil fuel burning and industrial activities in eastern China, dusts from the Central Asian deserts and particles produced in biomass burning in Sumatra and
Borneo can also reach the SCS. Their relative contributions vary spatially and temporally. In the northern SCS, the aerosol concentrations are the highest between November and April during the northeast monsoon when the prevailing wind carries the anthropogenic particles from China to the area. Between February and April, these particles are mixed with the dust particles from the Central Asian deserts. While the southwest monsoon can carry northwards the particles produced by biomass burning in Sumatra and Borneo, the weak wind and the long distance from the source region limit the penetration of these particles to the northern SCS. Since the geochemical characteristics of the particles from the different sources are not likely to be identical, their impact on the biogeochemistry of the northern SCS may also vary.

\subsection{Biological community structure}

Liu et al. (2007b) suggest that photo-adaptation can affect the photosynthetic process significantly in the shallower waters on the shelf. The effect was demonstrated at the SEATS station through modeling exercise. In marginal seas bordered by substantial shelf systems such as the SCS, photoadaptation is a critical process that should be taken into account in considering phytoplankton growth. Liu et al. (2007c) report that, at the SEATS station, Prochlorococcus is by far the most abundant among the autotrophic picoplankton. Synechococcus and picoeukaryotes are one to two orders of magnitude less abundant during most of the year. Seasonally, the smaller Prochlorococcus is more abundant in the summer when the water is warmer, more strongly stratified and more depleted in nutrients while the larger Synechococcus is more abundant in the winter when the water is colder and the concentrations of nutrients are higher (Tseng et al., 2005; Wong et al., 2007). In terms of total autotrophic biomass, the former constitutes $80 \%$ of it in the summer while the latter together with the picoeukaryotes can account for $60-80 \%$ of it in the winter. Chen et al. (2007) report that the nanoplankton coccolithophore also shows distinct seasonal variations, becoming more abundant in the colder and more nutrient-rich water in the winter and spring. Between the water in the deep basin and on the shelf, coccolithophore is more abundant during the colder seasons in the deep basin and during the warmer seasons in the shelf water. The relative abundance of coccolithophore and the other 
dominant nanoplankton, diatom, is controlled by the nutrient condition as the latter is favored in water that is more replete in nitrate and silicate. Lin and Hsieh (2007) observe that six species of foraminifera, Globigerinoides aequilateralis, G. sacculifer, G. menardii, G. rubber, Neogloboquadrina dutertrei and Pulleniatina obliquiloculata account for most of the foraminerferal shells found in the SCS. Their relative contributions vary seasonally and spatially: $G$. aequilateralis and $G$. merardii dominate in July, whereas $G$. sacculifer and $G$. rubber are dominant in October; while $G$. aequilateralis is dominant in the southern SCS, $P$. obliquiloculata is more abundant in the northern SCS. The relative abundance of $G$ a aequiliteralis in plankton tows is significantly higher than in sediments, suggesting that its tests may undergo dissolution upon burial. The $\delta^{18} \mathrm{O}$ of the calcium carbonate tests of $G$. rubber, G. sacculifer, $N$. dutertrei and $P$. obliquiloculata is found to be negatively correlated with temperature in the mixed layer such that their isotopic compositions may be used as paleothermometers. The temperatures recorded by the shallow dwelling species, G. sacculifer, and, the deep dwelling species, $N$. dutertrei, may potentially be used for reconstructing the past stratification in the upper water column.

\section{Acknowledgements}

The unwavering faith of the successive directors of NCOR, M.-P. Chen, Y.-H. Li, K.-K. Liu, C.-S. Liu and C.-S. Chern, and program managers of the Ocean Sciences Program of the National Science Council of Taiwan, D. D. Sheu, C.-L. Wei, C.-A. Huh, T.-Y. Tang and W.-T. Tsai on the scientific merit of a time-series station in the SCS and the continued financial support from the National Science Council of Taiwan are gratefully appreciated. The assistance of the captains and the crew of $\mathrm{R} / \mathrm{V}$ Ocean Researcher $\mathrm{I}$ and $\mathrm{R} / \mathrm{V}$ Ocean Researcher III and members of the Precious Instrument Center, and the participation of the scientists and post-doctoral fellows at NCOR and at National Taiwan University, National Sun-Yat Sen University and National Taiwan Ocean University are indispensable for the successful implementation of SEATS. This work was supported by Grant Numbers NSC 88-2119-M-002-002, 89-2119-M002-016, 90-2119-M-002-016, 91-2119-M-002-031 and $92-2119-\mathrm{M}-002-015$ to NCOR. This is NCOR Contribution No. 104.

\section{References}

Betzer, P.R., Showers, W.J., Laws, E.A., 1984. Primary productivity and particle fluxes on a transect of the equator at $153^{\circ} \mathrm{W}$ in the Pacific Ocean. Deep-Sea Research 31, $1-11$.

Brewer, P.G., Bruland, K.W., Eppley, R.W., McCarthy, J.J., 1986. The global ocean flux study (GOFS): status of the US GOFS program. EOS 44, 827-832.

Broecker, W.S., Patzert, W.C., Toggweiler, J.R., Stuiver, M., 1986. Hydrography, chemistry, and radioisotopes in the southeast Asian basins. Journal of Geophysical Research 91, 14345-14354.

Buesseler, K.O., 2001. Ocean biogeochemistry and the global carbon cycle; an introduction to the US Joint Global Ocean Flux Study. Oceanography 14, 5.

Cai, W.-J., Dai, M., 2004. Comment on "Enhanced open ocean storage of $\mathrm{CO}_{2}$ from shelf sea pumping". Science 306, 1477.

Cai, P., Huang, Y., Chen, M., Guo, L., Liu, G., Qiu, Y., 2002. New production based on 228Ra-derived nutrient budgets and thorium-estimated POC export at the intercalibration station in the South China Sea. Deep-Sea Research I 49, 53-66.

Calvert, S.E., Karlin, R.E., Toolin, L.J., 1991. Low organic carbon accumulation rates in Black Sea sediments. Nature 350, 692-695.

Capone, D.G., Zehr, J.P., Paerl, H.W., Bergman, B., Carpenter, F.J., 1997. Trichodesmium, a globally significant marine cyanobacterium. Science 276, 122-1229.

Capone, D.G., Burns, J.A., Montoya, J.P., Subramaniam, A., Mahaffey, C., Gunderson, T., Michaels, A.F., Carpenter, E.J., 2005. Nitrogen fixation by Trichodesmium spp.: an important source of new nitrogen to the tropical and subtropical North Atlantic Ocean. Global Biogeochemical Cycles 19.

Chao, S.-Y., Shaw, P.-T., Wang, J., 1995. Wind relaxation as a possible cause of the South China Sea warm current. Journal of Oceanography 51, 111-132.

Chao, S.-Y., Shaw, P.-T., Wu, S.S., 1996a. El Niño modulation of the South China Sea circulation. Progress in Oceanography $38,51-93$

Chao, S.-Y., Shaw, P.-T., Wu, S.S., 1996b. Deep water ventilation in the South China Sea. Deep-Sea Research I 43, 445-466.

Chen, C.-T.A., 2005a. Tracing tropical and intermediate waters from the South China Sea to the Okinawa Trough and beyond. Journal of Geophysical Research 110, c05012.

Chen, Y.-1.L., 2005b. Spatial and seasonal variations of nitratebased new production and primary production in the South China Sea. Deep-Sea Research I 52, 319-340.

Chen, Y.-Y., Chen, M.-T., Fang, T.-S., 1999. Biogenic sedimentation patterns in the northern South China Sea: an untrahigh-resolution record MD972148 of the past 150,000 years from the IMAGES III-IPHIS cruise. Terrestrial, Atmospheric and Oceanic Sciences 10, 215-224.

Chen, C.-T.A., Wang, S.-L., Wang, B.-J., Pai, S.-C., 2001. Nutrient budgets for the South China Sea basin. Marine Chemistry 75, 281-300

Chen, C.-T.A., Liu, K.-K., MacDonald, R.W., 2003a. Continental margin exchanges. In: Fasham, M.J.R. (Ed.), Ocean Biogeochemistry: The Role of the Ocean Carbon Cycle in 
Global Change. IGBP Book Series, Springer, New York, pp. 53-97.

Chen, Y.-1., Chen, H.-Y., Lin, Y.-H., 2003b. Distribution and downward flux of Trichodesmium in the South China Sea as influences by the transport from the Kuroshio current. Marine Ecology Progress Series 259, 47-57.

Chen, Y.-1.L., Chen, H.-Y., Karl, D.M., Takahashi, M., 2004. Nitrogen modulates phytoplankton growth in spring in the South China Sea. Continental Shelf Research 24, 527-541.

Chen, C.-T.A., Hou, W.-P., Gamo, T., Wang, S.L., 2006 a. Carbonate-related parameters of subsurface waters in the West Philippine, South China and Sulu Seas. Marine Chemistry 99, 151-161.

Chen, C.-C., Shiah, F.-K., Chung, S.-W., Liu, K.-K., 2006 b. Winter phytoplankton blooms in the shallow mixed layer of the South China Sea enhanced by upwelling. Journal of Marine Systems 59, 97-110.

Chen Y.-L. L., Chen, H.-Y., Chung, C.-W., 2007. Seasonal variability of coccolithophore abundance and assemblage in the northern South China Sea. Deep-Sea Research II, this issue [doi:10.1016/j.dsr2.2007.05.005].

Chou, W.-C., Chen, Y.-L.L., Sheu, D.D., Shih, Y.-Y., Han, C.-A., Cho, C.L., Tseng, C.-M., Yang, Y.-J., 2006. Estimated net community production during the summertime at the SEATS time-series study site, northern South China Sea: implications for nitrogen fixation. Geophysical Research Letters 32, L22610.

Chou, W.-C., Sheu, D.D., Lee, B.S., Tseng, C.M., Chen, C.T.A., Wang, S.L., Wong, G.T.F., 2007. Depth distributions of alkalinity, $\mathrm{TCO}_{2}$ and $\delta^{13} \mathrm{C}_{\mathrm{TCO} 2}$ at SEATS time-series site in the northern South China Sea. Deep-Sea Research II, this issue [doi:10.1016/j.dsr2.2007.05.002].

Dickey, T., Frye, D., McNeil, J., Manov, D., Nelson, N., Sigurdson, D., Jannasch, H., Siegel, D., Michaels, T., Johnson, R., 1998. Upper ocean temperature response to Hurricane Felix as measured by the Bermuda Testbed Mooring. Monthly Weather Review 126, 1195-1201.

Duce, R.A., Tinsdale, N.W., 1991. Atmospheric transport of iron and its deposition in the ocean. Limnology and Oceanography $36,1715-1726$.

Duce, R.A., Liss, P.S., Merrill, J.T., Atlas, E.L., Buat-Menard, P., Hicks, B.B., Miller, J.M., Prospero, J.M., Arimoto, R., Church, T.M., Ellis, W., Galloway, J.N., Hansen, L., Jickells, T.D., Knap, A.H., Rheinhardt, K.H., Schneider, B., Sudine, A., Tokos, J.J., Tsunogai, S., Wollast, R., Zhou, M., 1991. The atmospheric input of trace species to the world ocean. Global Biogeochemical Cycles 5, 193-259.

Eppley, R.W., Peterson, B.J., 1979. Particulate organic matter flux and planktonic new production in the deep ocean. Nature 282, 677-680.

Fung, I.Y., Meyn, S.K., Tegen, I., Doney, S.C., John, J.G., Bishop, J.K.B., 2000. Iron supply and demand in the upper ocean. Global Biogeochemical Cycle 14, 281-296.

Gan, J., Li, H., Curchitser, E.N., Haidvogel, D.B., 2006. Modeling South China Sea circulation: response to seasonal forcing regimes. Journal of Geophysical Research 111, C06034.

Gao, Y., Kaufman, Y.J., Tanré, D., Kolber, D., Falkowski, P.G., 2001. Seasonal distributions of aeolian iron fluxes to the global ocean. Geophysical Research Letters 28, 29-32.

Gong, G.C., Liu, K.K., Liu, C.T., Pai, S.C., 1992. The chemical hydrography of the South China Sea west of Luzon and a comparison with the West Philippine Sea. Terrestrial, Atmospheric and Oceanic Sciences 3, 587-602.

Gruber, N., Sarmiento, J.L., 1997. Global patterns of marine nitrogen fixation and denitrification. Global Biogeochemical Cycles 11, 235-266.

Hong Kong Observatory Climatological Information Services. Monthly meteorological normals for Hong Kong between 1971-2000. <http://www.hko.gov.hk/cis/normal/1971_2000/ normals_e.htm $\rangle$.

Huang, Q.-Z.', Wang, W.-Z., Li, Y.S., Li, C.W., 1994. Current characteristics of South China Sea. In: Zhou, D., Liang, Y.-B., Zeng, C.-K. (Eds.), Oceanology of China Seas, vol. 1. Kluwer, Dordrecht, pp. 39-47.

Hung, J.-J., Wang, S.-M., Chen, Y.-L., 2007. Biogeochemical controls on distributions and fluxes of dissolved and particulate organic carbon in the northern South China Sea. Deep-Sea Research II, this issue [doi:10.1016/j.dsr2. 2007.05.006].

Jennerjahn, T.C., Liebezeit, G., Kempe, S., Xu, L.Q., Chen, W.B., Wong, H.K., 1992. Particle flux in the northern South China Sea. In: Jing, X., Kudrass, H.R., Pautot, G. (Eds.), Marine Geology and Geophysics of the South China Sea. China Ocean Press, Beijing, pp. 228-235.

Jickells, T.D., An, Z.S., Andersen, K.K., Baker, A.R., Bergametti, G., Brooks, N., Cao, J.J., Boyd, P.W., Duce, R.A., Hunter, K.A., Kawahata, H., Kubilay, N., laRoche, J., Liss, P.S., Nahowald, N., Prospero, J.M., Ridgwell, A.J., Tegen, I., Torres, R., 2005. Global iron connections between desert dust, ocean biogeochemistry, and climate. Science 308, 67-71.

Karl, D.M., Lukas, R., 1996. The Hawaii Ocean Time-series (HOT) program: background, rationale and field implementation. Deep-Sea Research II 43, 129-156.

Karl, D.M., Michaels, A.F., 1996. Preface: The Hawaiian Ocean Time-series (HOT) and Bermuda Atlantic time-series study (BATS). Deep-Sea Research II 43, 127-128.

Karl, D.M., Letelier, R., Tupas, L., Dore, J., Christian, J., Hebel, D., 1997. The role of nitrogen fixation in biogeochemical cycling in the subtropical North Pacific Ocean. Nature 388, 533-538.

Karl, D.M., Dore, J.E., Lukas, R., Michaels, A.F., Bates, N.R., Knapp, A., 2001. Building the long-term picture: the US JGOFS time-series programs. Oceanography 14, 6-17.

Karl, D.M., Bates, N., Emerson, S., Harrison, P.J., Jeandel, C., Llinás, O., Liu, K.K., Marty, J.-C., Michaels, A.F., Miquel, J.C., Neuer, S., Nojiri, Y., Wong, C.S., 2003. Temporal studies of biogeochemical processes determined from ocean time-series observations during the JGOFS era. In: Fasham, M.J.R. (Ed.), Ocean Biogoechemistry: The Role of the Ocean Carbon Cycle in Global Change. International GeosphereBiosphere Programme Book Series. Springer, New York, pp. 239-268.

Lee, M.-Y., Wei, K.-Y., Chen, Y.-G., 1999. High resolution oxygen isotope stratigraphy for the last 150,000 years in the southern South China Sea: Core MD972151. Terrestrial, Atmospheric and Oceanic Sciences 10, 239-254.

Li, L., Qu, T., 2006. Thermohaline circulation in the deep South China Sea basin inferred from oxygen distributions. Journal of Geophysical Research 111, C05017.

Lin, H.-L., Hsieh, H.-Y., 2007. Seasonal variations of modern planktonic foramifera in the South China Sea. Deep-Sea Research II, this issue [doi:10.1016/j.dsr2.2007.05.007]. 
Lin, I., Liu, T., Wu, C.-C., Wong, G.T.F., Hu, C., Chen, Z., Liang, W.-D., Yang, Y., Liu, K.-K., 2003. New evidence for enhanced ocean primary production triggered by tropical cyclone. Geophysical Research Letters 30 (13), 1718

Lin, I.-I., Chen, J.-P., Wong, G.T.F., Huang C.-W., Lien, C.-C., 2007. Aerosol input to the South China Sea: results from the Moderate resolution imaging spectro-radiometer, the quick scatterometer, and the measurements of pollution in the troposphere sensor. Deep-Sea Research II, this issue [doi:10.1016/j.dsr2.2007.05.013].

Liu, K.K., Iseki, K., Chao, S.Y., 2000. Continental margin carbon fluxes. In: Hanson, R.B., Ducklow, H.W., Field, J.G. (Eds.), The Changing Ocean Carbon Cycle: A Midterm Synthesis of the Joint Global Ocean Flux Study. IGBP Book Series, Cambridge University Press, Cambridge, pp. 187-239.

Liu, K.-K., Chao, S.-Y., Shaw, P.-T., Gong, G.-C., Chen, C.-C., Tang, T.-Y., 2002. Monsoon-forced chlorophyll distribution and primary production in the South China Sea: observations and a numerical study. Deep-Sea Research I 49, $1387-1412$.

Liu, K.-K., Peng, T.-H., Shaw, P.-T., Shiah, F.-K., 2003. Circulation and biogeochemical processes in the East China Sea and the vicinity of Taiwan: an overview and a brief synthesis. Deep-Sea Research II 50, 1055-1064.

Liu, C.-T., Pinkel, R., Hsu, M.-K., Klymak, J.M., Chen, H.-W., Villanoy, C., 2006. Nonlinear internal waves from the Luzon Strait. EOS 87 (42), 449-451.

Liu, K.-K., Kao, S.-J., Hu, H.-C., Chou, W.-C., Hung G.-W., Tseng, C.-M., 2007a. Carbon isotopic composition of suspended and sinking particulate organic matter in the northern South China Sea-from production to deposition. Deep-Sea Research II, this issue [doi:10.1016/j.dsr2. 2007.05.010].

Liu, K.-K., Chen, Y.-J., Tseng, C.-M., Lin, I.-I., Liu, H.-B., Snidvongs, A., 2007b. The significance of phytoplankton photo-adaptation and benthic-pelagic coupling to primary production in the South China Sea: observations and numerical investigations. Deep-Sea Research II, this issue [doi:10.1016/j.dsr2.2007.05.009].

Liu, H., Chang, J., Tseng, C.-M., Wen, L.-S., Liu, K.K., 2007 c. Seasonal variability of picoplankton in the northern South China Sea at the SEATS station. Deep-Sea Research II, this issue [doi:10.1016/j.dsr2.2007.05.004].

Liu, K.-K., Tseng, C.-M., Wu, C.-R., Lin, I.-I., 2007. South China Sea. In: Liu, K.-K., Atkinson, L., Quiñones, R., Talaue-McManus, L. (Eds.), Carbon and Nutrient Fluxes in Continental Margins: A Global Synthesis. IGBP Book Series. Springer, New York, in press.

Mahaffey, C., Michaels, A., Capone, D.G., 2005. The conundrum of marine nitrogen fixation. American Journal of Science 305, 546-595.

McCarthy, J.J., 2000. The evolution of the joint global ocean flux study project. In: Hanson, R.B., Ducklow, H.W., Field, J.G. (Eds.), The Changing Ocean Carbon Cycle. Cambridge University Press, Cambridge, UK, pp. 3-15.

McGillicuddy Jr., D.J., Robinson, A.R., 1997. Eddy-induced nutrient supply and new production in the Sargasso Sea. Deep-Sea Research I 44, 1427-1450.

McGillicuddy Jr., D.J., Robinson, A.R., Siegel, D.A., Jannasch, H.W., Johnson, R., Dickey, T.D., McNeil, J., Michaels, A.F.,
Knap, A.H., 1998. Influence of mesoscale eddies on new production in the Sargasso Sea. Nature 394, 283-286.

Milliman, J.D., Meade, R.H., 1983. Worldwide delivery of river sediment to the oceans. Journal of Geology 91, 1-21.

Montoya, J.P., Holl, C.M., Zehr, J.P., Hansen, A., Villareal, T.A., Capone, D.G., 2004. High rates of $\mathrm{N}_{2}$ fixation by unicellular diazotrophs in the oligotrophic Pacific Ocean. Nature 430, 1027-1031.

Ning, X., Chai, F., Xue, H., Cai, Y., Liu, C., Shi, J., 2004. Physical-biological oceanographic coupling influencing phytoplankton and primary production in the South China Sea. Journal of Geophysical Research 109, C10005.

Oschlies, A., Garçon, V., 1998. Eddy-induced enhancement of primary production in a model of the North Atlantic Ocean. Nature 394, 266-269.

Parsons, T.R., Takahashi, M., Hargrave, B., 1977. Biological Oceanographic Processes, second ed. Pergamon, Oxford, 332pp.

Paerl, J.W., 1997. Coastal eutrophication and harmful algal blooms: importance of atmospheric deposition and groundwater as "new" nitrogen and other nutrient sources. Limnology and Oceanography 42 (5, part 2), 1154-1165.

Pilson, M.E.Q., 1998. An Introduction to the Chemistry of the Sea. Prentice-Hall, Upper Saddle River, NJ, 269pp.

Pinet, P.R., 2006. Invitation to Oceanography, Forth ed. Jones and Bartlett, Boston, 594pp.

Qu, T., Girton, J.B., Whitehead, J.A., 2006. Deepwater overflow through Luzon Strait. Journal of Geophysical Research 111, C01002.

Rehder, G., Suess, E., 2001. Methane and $p \mathrm{CO}_{2}$ in the Kuroshio and the South China Sea during maximum summer surface temperatures. Marine Chemistry 75, 89-108.

Redfield, A.C., Ketchum, B.H., Richards, F.A., 1963. The influence of organisms on the composition of sea-water. In: Hill, M.N. (Ed.), The Sea, vol. 2. Interscience, New York, pp. $26-77$.

SCOR, 1990. The Joint Global Ocean Flux Study. JGOFS. Science Plan. JGOFS Report No. 5. Scientific Committee on Oceanic Research, International Council of Scientific Unions. Dalhousie University, Halifax, Canada, 61pp.

SCOR, 1992. Joint Global Ocean Flux Study Implementation Plan. JGOFS Report No. 9. Scientific Committee on Oceanic Research, International Council of Scientific Unions. Johns Hopkins University, Baltimore, MD, 75pp.

Shaw, P.-T., Chao, S.-Y., 1994. Surface circulation in the South China Sea. Deep-Sea Research I 41, 1663-1683.

Shaw, P.-T., Chao, S.-Y., Liu, K.-K., Pai, S.-C., Liu, C.-T., 1996. Winter upwelling off Luzon in the northeastern South China Sea. Journal of Geophysical Research 101, 16435-16448.

Shaw, P.-T., Chao, S.-Y., Fu, L.-L., 1999. Sea surface height variations in the South China Sea from satellite altimetry. Oceanologica Acta 22, 1-17.

Shiah, F.-K., Liu, K.-K., Tang, T.-Y., 1999. South East Asian Time-series Station established in South China Sea. US JGOFS Newsletter 10 (1), 8-9.

Suga, T., Kato, A., Hanawa, K., 2000. North Pacific Tropical Water: its climatology and temporal changes associated with the climate regime shift in the 1970s. Progress in Oceanography $47,223-256$.

Sverdrup, H.U., Johnson, M.W., Fleming, R.H., 1942. The Oceans Their Physics Chemistry and General Biology. Prentice-Hall, Englewood Cliffs, NJ, 1087pp. 
Thomas, H., Bozec, Y., Elkalay, K., de Baar, H.J., 2004. Enhanced open ocean storage of $\mathrm{CO}_{2}$ from shelf sea pumping. Science 304, 1005-1008.

Tseng, C.-M., Wong, G.T.F., Lin, I.-I., Wu, C.-R., Liu, K.-K., 2005. A unique seasonal pattern in phytoplankton biomass in low-latitude waters in the South China Sea. Geophysical Research Letters 32, L08608.

Tseng, C.-M., Wong, G.T.F., Chou, W.-C., Lee, B.-S., Sheu, D.D., Liu, K.-K., 2007. Temporal variations in the carbonate system in the upper layer at the SEATS station. Deep-Sea Research II, this issue [doi:10.1016/j.dsr2.2007.05.003].

USGOFS, 1986. USGOFS Report 3. Report of a Workshop on Upper Ocean Processes. US Joint Global Ocean Flux Study (JGOFS) Planning Office, Woods Hole, MA, 141pp.

USGOFS, 1990. USGOFS Report 11. Joint Global Ocean Flux Study. Long Range Plan. The Role of Ocean Biogeochemical Cycles in Climate Change. US Joint Global Ocean Flux (JGOFS) Planning Office, Woods Hole, MA, 71pp.

Wang, P., Wand, L., Bian, Y., Jian, Z., 1995. Late quaternary paleoceanography of the South China Sea: surface circulation and carbonate cycles. Marine Geology 127, 145-165.

Wang, G., Su, J., Chu, P.C., 2003. Mesoscale eddies in the South China Sea observed with altimeter data. Geophysical Research Letters 30 (21), 2121.

Wen, L.-S., Jiann, K.-T., Santschi, P.H., 2006. Physicochemical speciation of bioactive trace metals $(\mathrm{Cd}, \mathrm{Cu}, \mathrm{Fe}, \mathrm{Ni})$ in the oligotrophic South China Sea. Marine Chemistry 101, 104-129.

Wiebe, P.H., Miller, C.B., McGowan, J.A., Knox, R.A., 1987. Long time series study of oceanic ecosystems. EOS 44, 1178-1190.

Wong, G.T.F., Li, Y.-H., Chao, S.-Y., Chung, Y.-C., 2000a. Preface. Continental Shelf Research 20, 331-334.

Wong, G.T.F., Chao, S.-Y., Li, Y.-H., Shian, F.-K., 2000b. The Kuroshio Edge Exchange Processes (KEEP) study-an introduction to hypotheses and highlights. Continental Shelf Research 20, 335-348.
Wong, G.T.F., Chung, S.-W., Shiah, F.-K., Chen, C.-C., Wen, L.-S., Liu, K.-K., 2002. Nitrate anomaly in the upper nutricline in the northern South China Sea-evidence for nitrogen fixation. Geophysical Research Letters 29 (23), 2097.

Wong, G.T.F., Tseng, C.-M., Wen, L.-S., Chung, S.-W., 2007. Nutrient dynamics and nitrate anomaly at the SEATS station. Deep-Sea Research, this issue [doi:10.1016/j.dsr2. 2007.05.011]

Wu, C.-R., Chiang, T.L., 2007. Mesoscale eddies in the northern South China Sea. Deep-Sea Research, this issue [doi:10.1016/ j.dsr2.2007.05.008].

Wu, J., Chung, S.-W., Wen, L.-S., Liu, K.-K., Chen, Y.L., Chen, H.-Y., Karl, D.M., 2003. Dissolved inorganic phosphorus, dissolved iron, and Trichodesmium in oligotrophic South China Sea. Global Biogeochemical Cycles 17 (1), 1008.

Xie, S.-P., Xie, Q., Wang, D., Liu, W.T., 2003. Summer upwelling in the South China Sea and its role in regional climate variations. Journal of Geophysical Research 108 (C8), 3261.

Xue, H., Chai, F., Pettigrew, N., Xu, D., Shi, M., Xu, J., 2004. Kuroshio intrusion and the circulation in the South China Sea. Journal of Geophysical Research 109, C02017.

You, Y., 2003. The pathway and circulation of North Pacific Intermediate Water. Geophysical Research Letters 30 (24), 2291.

Zhai, W., Dai, M., Cai, W.-J., Wang, Y., Hong, H., 2005. The partial pressure of carbon dioxide and air-sea fluxes in the northern South China Sea in spring, summer and autumn. Marine Chemistry 96, 87-97.

Zhang, J., 1995. Geochemistry of trace metals from Chinese river/ estuary systems: an overview. Estuarine, Coastal and Shelf Science 41, 631-658.

Zhang, J., 1996. Nutrient elements in large Chinese estuaries. Continental Shelf Research 16, 1023-1045.

Zhang, J., Huang, W.-w., Liu, M.-g., 1994. Geochemistry of major Chinese river-estuary systems. In: Zhou, D., Liang, Y.-B., Zeng, C.-K. (Eds.), Oceanology of China Seas, vol. 1. Kluwer, Dordrecht, pp. 179-188. 